\title{
Transatlantica
}

Revue d'études américaines. American Studies Journal

\section{T.R. Reid, The Healing of America: A Global Quest for Better, Cheaper, and Fairer Health Care, New York, The Penguin Press, 2009, 277p}

\section{Éveline Thévenard}

\author{
(2) OpenEdition \\ Journals \\ Édition électronique \\ URL : https://journals.openedition.org/transatlantica/4765 \\ DOI : $10.4000 /$ transatlantica.4765 \\ ISSN : $1765-2766$ \\ Éditeur \\ Association française d'Etudes Américaines (AFEA) \\ Référence électronique \\ Éveline Thévenard, «T.R. Reid, The Healing of America: A Global Quest for Better, Cheaper, and Fairer \\ Health Care, New York, The Penguin Press, 2009, 277p », Transatlantica [En ligne], 2 | 2009, mis en \\ ligne le 01 février 2010, consulté le 31 janvier 2023. URL : http://journals.openedition.org/ \\ transatlantica/4765 ; DOI : https://doi.org/10.4000/transatlantica.4765
}

Ce document a été généré automatiquement le 31 janvier 2023.

\section{(c) (i) (9)}

Creative Commons - Attribution - Pas d'Utilisation Commerciale - Pas de Modification 4.0 International - CC BY-NC-ND 4.0

https://creativecommons.org/licenses/by-nc-nd/4.0/ 


\title{
T.R. Reid, The Healing of America: A Global Quest for Better, Cheaper, and Fairer Health Care, New York, The Penguin Press, 2009, 277p
}

\author{
Éveline Thévenard
}

1 The U.S. Interstate Highway System was inspired by Germany's. Sushi and pizza have become some of America's favorite foods. So why not borrow from foreign models to reform the most expensive and inequitable health care system in the developed world?

2 U.S. researchers' interest in cross-national comparative studies has increased in recent years, and scholarly journals such as Health Affairs and the Journal of Health Politics Policy and Law regularly devote space to analyses of health care financing and delivery in developed countries. Even the mainstream press now regularly features accounts of the quality and accessibility of the care available under systems that used to be considered inferior to that of "the best in the world."

3 Through his tour of several rich industrialized countries' hospitals and doctors' offices and his interviews with health authorities, Washington Post journalist T.R. Reid sets out to find a cure both for his ailing shoulder and for America's troubled health care system while attempting to solve a conundrum: why is the U.S., the world leader in so many areas, doing worse than many other countries (including developing countries) in terms of health care costs, access, quality, and even choice? The result is an instructive, lively, and highly readable primer on the history and current features of major health systems, and a vibrant call for radical change at home. Using the story of Nikki White, a young American woman who died of a curable disease - lupus - because she was denied coverage by her insurer, as a metaphor of everything that is wrong with U.S. health care, he goes on to demonstrate that some nations could be a source of inspiration for the U.S., which was ranked $37^{\text {th }}$ in the 2000 WHO study on health systems performance.

Reid picked advanced democracies which offer variations on one of the three basic health care models (Bismarck, Beveridge, National health insurance), are faced with the 
same problems as the U.S. (rising costs and an aging population), and get high quality ratings in international surveys. His global quest leads him to (among other places) Canada, France, Germany, the U.K. and Japan, but also to two countries, Taiwan and Switzerland, which have successfully overhauled their systems in recent years to make them accessible to all.

He discovers a wide diversity in billing mechanisms, in the status of medical providers (private or public), and in the type of care that is offered for the same condition (Reid is advised to undergo major surgery by his U.S. orthopedist, while his British NHS doctor simply tells him his condition is not serious enough to warrant an expensive operation, and his French doctor recommends physiotherapy). But no matter how diverse these systems are, reflecting national histories and cultural differences, they all share a common set of basic principles stemming from ethical choices that the U.S. has so far failed to make: health care is viewed as a right, just like education, guaranteed by these countries' constitutions or legal systems; access to treatment must not be function of the patient's ability to pay; universal coverage is the rule; and health insurance cannot be a profit-making business, although the provision of medical services can. Most of the problems that plague the inequitable, costly and inefficient U.S. health care system have their root causes in the reluctance to make the moral issue the core issue, with the result that the insurance industry has been allowed to set the rules for the provision of health coverage to most Americans, depriving of care those who need it the most. In other countries, private insurers can only make profits on the sale of supplemental benefits, while basic, universal coverage is provided by non-profit entities or by the government.

Reid enumerates the well-known facts and figures which show the U.S. is an outlier in international comparisons of health outcomes and costs, which has made it increasingly difficult for all but the staunchest conservatives to defend American exceptionalism. It performs poorly, compared to other rich countries, in terms of infant mortality, life expectancy, and amenable mortality. 46 million are uninsured, millions more are underinsured, and medical bankruptcies, which are nonexistent in other developed countries, affect 700,000 Americans a year. And although all developed countries have seen their costs rise, the U.S. far outpaces its counterparts in health expenditures as a share of GDP, increasing the budget deficit and undermining the competitiveness of American businesses. Although the profit-oriented insurance industry is largely to blame for the soaring premiums, the complexity of a fragmented system with a multiplicity of payers and rules generates inefficiency, waste, and high administrative costs.

While the U.S. health care system does not fit into any existing model, it incorporates elements of England's Beveridge model (with programsfinanced and deliveredby thefederalgovernment for the military and Native Americans), Canada's National Insurance model (Medicare, where services are publicly financed but delivered by the private sector), and Germany and France's Bismarck model (the employer based system, which is the way most people under 65 get insurance). So in his global search for clues to why other countries' systems work better than the U.S. system, Reid finds surprising similarities but also shocking differences.

8 Thus France (which ranks first in many global studies based on several indicators) and the U.S. are both attached to fee for service, providers in both countries are usually in the private sector, and both systems are for the most part financed by workers' and 
employers' contributions. But the French get comprehensive, first-dollar coverage, insurance entities are non-profit, and providers have to comply with a single set of rules for payment of services. While the Obama Administration's support for electronic medical records in January 2009 triggered a heated controversy, the French implemented such a system years ago along with a computerized billing system, cutting administrative costs. The British and Canadian systems, regularly the butt of ideological attacks in the conservative media, get high marks for their accessibility (no bills to pay), low costs, and an emphasis on prevention and primary care. And Reid suggests that just as Saskatchewan, a health insurance pioneer, paved the way for the 1984 Canada Health Act, the 2006 Massachusetts reform, which has sharply reduced the number of uninsured, could provide a blueprint for a federal health care overhaul.

9 This informative and realistic account does not underestimate the problems, dilemmas, and hard decisions that all countries are faced with. There is no perfect system, and Reid highlights their limitations as well as their achievements. Everywhere health care costs are exploding, leading governments to adopt or attempt to adopt cost-control measures that are unpopular with patients and doctors. In his straightforward review of the pluses and minuses of the Canadian system, he does not pass over its problem of waiting lists for elective procedures, but in the end the system still comes out as a winner. Reid also redefines notions that are the bedrock of conservative ideology, such as choice and rationing, which the U.S. conservative establishment and industry interests have brandished for decades in order to prevent passage of meaningful reform.

10 In the countries Reid visited, people give up the freedom to choose for themselves whether to be insured or not, or to choose their insurance plan. The individual and employer mandates that feature for the first time in the 2009 U.S. reform bills have been the foundation of their health care systems for years, spreading risks and cementing social solidarity. But in return, the citizens of Europe, Canada, and Japan gain the freedom to choose their providers, while most Americans are limited to those within their insurance plan's network. Americans' much touted freedom of choice, which according to the American right wing would be severely curtailed with a government run system or tight regulation of insurers, is in most cases a myth. And in all countries, the author noted an unequivocal rejection of market-driven health care. The few countries that have tried to replicate the U.S. model have either reversed course (Switzerland) or suffered a deterioration of their population health (China).

Reid does not evade another highly sensitive issue: rationing, which would, according to conservative ideology, inevitably occur with a sweeping reform of the U.S. health care where government agencies would control the health care budget and decide which procedures are covered. Yes, foreign countries ration care in one way or another: in Canada, long lines and a shortage of sophisticated medical equipment lead to a de facto rationing of care - for everybody. In Britain, as the Health Minister puts it in very plain terms, "we cover everybody, we don't cover everything." NICE, the British agency which evaluates the cost effectiveness of treatments, was the target of scathing and slanderous attacks in the U.S. in January 2009, when conservatives argued that the comparative effectiveness studies financed with money from the stimulus package would lead to denial of care, as in Britain. But a far more inequitable form of rationing occurs on a daily basis in the U.S., when insurance companies refuse to enrol people with a pre-existing condition, when they cancel their policies after they become sick or 
raise premiums to such levels that they become unaffordable to many people and businesses.

12 Reid's conclusion is an invitation to draw the lessons of foreign experience, to reflect on what kind of inequalities Americans are prepared to tolerate, and to rethink the priorities that ought to shape future health care reform. The perennial debate over which should come first, universal access or cost control, is a no-brainer: other countries have not designed their health care system around costs, but around their national values and concern for equity. In addition, Reid's global quest shows that universal coverage and a unified administrative system are the necessary conditions for cost control and improved quality. It is high time the moral issue which has been relegated to the sidelines since the 1960s, and superseded by economic considerations, took center stage. Any attempt to tinker with the current fragmented system is bound to fail. American health care needs major surgery.

INDEX

Thèmes : Recensions

\section{AUTEUR}

ÉVELINE THÉVENARD

Paris-Sorbonne 